\title{
Phytoremediation of industrial wastewater potentiality by Typha domingensis
}

\author{
${ }^{1}$ A. K. Hegazy; ${ }^{2}$ N. T. Abdel-Ghani; ${ }^{3}$ G. A. El-Chaghaby \\ ${ }^{1}$ Department of Botany and Microbiology, College of Science, King Saud University, Riyadh, Saudi Arabia \\ ${ }^{2}$ Department of Chemistry, Faculty of Science, Cairo University, Egypt \\ ${ }^{3}$ Agriculture Research Center, Giza, Egypt
}

Received 26 October 2010; $\quad$ revised 23 December 2010; accepted 20 February 2011; $\quad$ available online 1 June 2011

\begin{abstract}
Phytoremediation is increasingly receiving attention as a cost effective technique that uses plants to remediate contaminants from wastewater, soil and sediments. In this study, the ability of Typha domingensis to uptake heavy metals as well as its potential application for phytoremediation was assessed. Pollutant elements concentrations were measured in samples of wastewater, sediments and Typha domingensis collected from industrial wastewater ponds, El-Sadat city, Egypt. This study specifically focused on the capacity of Typha domingensis to absorb and accumulate aluminum, iron, zinc and lead. Results indicated thatTypha domingensis was capable of accumulating the heavy metal ions preferentially from wastewater than from sediments. The accumulation of metals in plant organs attained the highest values in roots, rhizomes and old leaves. Rhizofiltration was found to be the best mechanism to explain Typha domingensis phytoremediation capability.
\end{abstract}

Keywords: Aluminium; Bioconcentration factor; El-Sadat city; Iron; Lead; Rhizofiltration; Translocation factor; Zinc

\section{INTRODUCTION}

The industrial sector is an important consumer of both natural resources and a contributor to environmental pollution. The spatial distribution of industry in Egypt is influenced by the size of the employment pool, availability of services, access to transportation networks and proximity to principal markets. The manufacturing facilities are therefore often located within the boundaries of major cities as Greater Cairo and Alexandria.

The program of Eco-friendly industrial cities (Hamza, 2001) launched by the Egyptian government aims at boosting various initiatives of cleaner production in the industrial establishments. One of the important new industrial Egyptian cities is El-Sadat city located between Cairo and Alexandria by the kilo 93 Cairo / Alexandria desert road. The main economic bases in the city, which has an area of $500 \mathrm{~km}^{2}$, are industrial activities. The industry sector includes many important activities which are: iron $\left(\mathrm{Fe}^{3+}\right)$ and steel, yarn and textile dying, building and construction, food products and beverage, ready made garments, engineering and metal production, electronics and electricity ware, wood products and furniture, plastic products and chemicals, transport equipments, paper products, poultry, industrial gases and medical products.

Discharge of untreated or partially treated industrial and domestic wastewater, leaching of pesticides and residues of fertilizers and transportation activities are the most important factors that affect the quality of ground and nearby surface water bodies (Ezzat et al., 2002). In Egypt, the degradation of water quality is a major issue, particularly; industrial discharges produce high levels of pollutants that can subsequently contaminate the soil, sediments and surface water systems (Förstner and Salomons, 1991; Dekov, 1997; Evangelou, 1998). As such there has been a great deal 
of research into finding cost effective methods for the removal of contaminants from wastewater (AbdelGhani et al, 2008; Al-Anber et al, 2008). Phytoremediation methods are comparatively cheap and ecologically advantageous, compared to other common technological approaches. There are several species of plants known for their phytoremediative abilities (Riffat et al, 2007; Nouri et al., 2009; 2011). The phytoremediation potentials of plant species have been considered in many previous researches (Sharifi et.al, 2007; Singh et.al, 2007; Zhang et.al, 2009).

Typha domingensis the subject of the present study is a widespread and dominant plant species in many aquatic systems in Egypt. T. domingens is is a tall (2.0$2.5 \mathrm{~m}$ ) perennial marsh that occurs naturally in both pristine and disturbed habitats with widely fluctuating water levels (Boulos, 2009), such as the industrial wastewater ponds in El-Sadat city, Egypt. This species can act as an aggressive invader and can completely choke lakes, ditches and canals.

The objectives of the present study were: 1) to evaluate the uptake and accumulation of metal pollutants in different organs of $T$. domingensis growing in industrial wastewater ponds and 2) to assess the correlations between metal pollutants content in wastewater sediment plant system as an important asset for potential use of the species in phytoremediation of industrial wastewaters. The study was carried out during 2009 at El-Sadat city, Egypt.

\section{MATERIALS AND METHODS}

Study area

The study area is located in the industrial zone of El-Sadat city in Menoufia governorate, Egypt (latitude $30^{\circ} 22^{\prime} 30^{\prime \prime} \mathrm{N}$ and longitude $30^{\circ} 30^{\prime} 1^{\prime \prime} \mathrm{E}$ ).

\section{Collection of wastewater, sediments and plant samples}

Grab samples of wastewater were collected from the main wastewater pond that received the direct industrial effluent at the study area (David et al., 2007). Wastewater samples were digested following the "nitric acid digestion procedure" described by APHA et al. (1998).

Sediment samples were collected from the study area (about $30 \mathrm{~cm}$ depths) then air dried to constant weight and then sieved through $2 \mathrm{~mm}$ stainless steel sieve. After homogenization, samples were kept in paper bags and preserved in desiccators for analysis. The sediment $\mathrm{pH}$ was determined potentiometrically in 1:2.5 (sediment: de-ionized water suspension) ratio (Maria et al., 2008). Sediment samples were digested following the "AOAC official method 990.08" described by AOAC (2002a).

T. domingensis plants were collected from the study area and separated into rhizomes and roots, leaf bases, leaf green parts and yellow leaf parts. Plant tissue samples were thoroughly washed with running tap water and rinsed with deionized water to remove any sediment particles attached to the plant surfaces. Plant tissue samples were macerated and oven dried at $70{ }^{\circ} \mathrm{C}$ to constant weight, then the dried materials were ground into powder and preserved in paper bags in a desiccator for subsequent analysis. The samples were digested following the procedure described by the "AOAC official method 985.01" described by AOAC (2002b).

\section{Determination of metals}

Metals concentrations in the wastewater, sediment and plant samples were determined by Inductively Coupled Plasma ICP-OES (Perkin Elmer, Optima 2000 DV) using argon and nitrogen gases. The instrument working wavelengths were set as suggested by the APHA et al. (1998).

\section{Evaluation of phytoremediation parameters}

The Bioconcentration factor (BCF) is a dimensionless factor also called bioaccumulation factor or enrichment coefficient, was calculated as the ratio of a given element concentration in the plant tissues at harvest to the concentration of the element in the external environment according to Eq.1 (Sutapa and Bhattacharyya, 2008)

$\mathrm{BFC}=\mathrm{P} / \mathrm{E}$

Where $\mathrm{P}$ represents the element concentration in plant tissues (mg/kg dry wt t) and E represents the element concentration in the water $(\mathrm{mg} / \mathrm{L})$ or in the sediment (mg/kg dry wt). A larger ratio implies better phytoaccumulation capability.

Translocation factor (TF) was calculated by dividing the concentration of a trace element accumulated in the root tissues by that accumulated in shoot tissues (Sutapa and Bhattacharyya, 2008). TF is given by Eq. 2.

$\mathrm{TF}=\left(\mathrm{A}_{\mathrm{s}} / \mathrm{A}_{\mathrm{r}}\right)$ 
Where $A_{r}$ represents the amount of trace element accumulated in the roots $(\mathrm{mg} / \mathrm{kg} \mathrm{dw})$ and $\mathrm{A}_{\mathrm{s}}$ represents the amount of trace element accumulated in the shoots $(\mathrm{mg} / \mathrm{kg} \mathrm{dw})$. TF is also called translocation capability and is dimensionless factor where a larger ratio implies higher translocation capability.

\section{Statistical analysis}

All analysis results (average of four replicates) were subjected to statistical treatment to determine the mean, standard deviation, relative standard deviation, significance and correlation coefficients. All statistics were calculated using Microsoft Excel 2007 and the SPSS 11.0.

\section{RESULTS AND DISCUSSION}

Wastewater analysi

The wastewater analysis results are shown in Table 1. All pollutant concentrations determined in the different wastewater samples were directly compared to the Egyptian environmental legal requirements for industrial wastewater (EEAA, 1994; EEAA, 2002; Daifullah et al., 2003). High levels of total dissolved solids (TDS) were quantified in the industrial wastewater pond (Table 1). The EPA suggests a maximum level of $250 \mathrm{mg} / \mathrm{L}$ in fresh water to minimize harm to humans and aquatic life (US EPA, 2001). Although a range of TDS concentrations are natural within aquatic systems, the high values observed in the wastewater ponds for the present study are likely due to anthropogenic wastewater releases by local residents or industry (Janel and Emily, 2006).

Nutrient concentrations in wastewater tend to be highly variable and industry-specific. Wastewater from industrial effluent often contains nitrogen $(\mathrm{N})$ and phosphorus (P) concentrations in excess of 200 and 20 $\mathrm{mg} / \mathrm{L}$, respectively (Phillips, 2002). Increased amounts of nitrogen and phosphorus found in wastewater ponds are the result of industrial wastewater discharge (Yale Center for Environmental Law and Policy, 2008). Among cations that occur abundantly in wastewater $\left(\mathrm{Na}^{+}, \mathrm{Ca}^{2+}\right.$, $\mathrm{Mg}^{2+}$ and $\mathrm{K}^{+}$), sodium was the most abundant whereas magnesium had the lowest concentration (Table 1 ).

Four metal ions in this study exceeded the permissible limits indicated by the Egyptian environmental regulations (Daifullah et al., 2003) (EEAA, 1994; 2002) for wastewater discharge. Based on these results, further experiments were focused on the following four metal ions viz., aluminum $\left(\mathrm{Al}^{3+}, \mathrm{Fe}^{3+}\right.$, zinc $\left(\mathrm{Zn}^{2+}\right)$ and lead $\left(\mathrm{Pb}^{2+}\right)$.
The presence of large amounts of $\mathrm{Al}^{3+}, \mathrm{Fe}^{3+}, \mathrm{Zn}^{2+}$ and $\mathrm{Pb}^{2+}$ is related to the major industries existing in the city. These include iron and steel production factory which accounts for the high level of $\mathrm{Fe}^{3+}$ found in wastewater, $\mathrm{Al}^{3+}$ presence may be attributed to the presence of food products and beverage facilities, whereas the presence of electronics and electricity industrial activities could be the responsible for the existence of $\mathrm{Zn}^{2+}$ and $\mathrm{Pb}^{2+}$ (Evangelou, 1998).

\section{Sediments analysis}

Sediments act as sinks for many contaminants, however the presence of elevated contaminant concentrations in sediments may have implications to the integrity of ecological systems (Mercedes et al., 1998). The sediment $\mathrm{pH}$ was found to be slightly alkaline with a value of 7.50 which is suitable for the growth of many plant species (Lindsay, 1979). The sediment samples were then analyzed for their $\mathrm{Al}^{3+}$, $\mathrm{Fe}^{3+}, \mathrm{Zn}^{2+}$ and $\mathrm{Pb}^{2+}$ contents. Table 2 demonstrates a comparison between the tested metal ions concentrations in sediments and the common, critical and ecotoxic ranges of metals in soils and sediments.

As can be seen from Table 2, the critical amounts of $\mathrm{Zn}^{2+}$ and $\mathrm{Pb}^{2+}$ ions are present in the sediments. The investigated lake sediments exceeded the upper eco-toxic threshold value limits for $\mathrm{Zn}^{2+}$ and $\mathrm{Pb}^{2+}$ as established by the U. S. Environmental Protection Agency in the sediment (US EPA, 1996). These two metals also were in the critical concentration range of metals in soils (Kabata and Pendias, 1992). Equilibrium exists between sediments and water, as such sediment acts as the ultimate repository for many contaminants. Thus, in order to correlate the water and sediments content of the metal ions, Pearson's correlation coefficients were calculated. The correlation coefficients were found to be: $\mathrm{Al}_{\mathrm{s}} / \mathrm{Al}_{\mathrm{w}}$ (1.00), $\mathrm{Fe}_{\mathrm{s}} / \mathrm{Fe}_{\mathrm{w}}$ (0.977), $\mathrm{Zn}_{\mathrm{s}} / \mathrm{Zn}_{\mathrm{w}}(0.968)$ and $\mathrm{Pb}_{\mathrm{s}} / \mathrm{Pb}_{\mathrm{w}}(0.808)$ indicating that all the studied metals concentrations in water and sediments are positively correlated implying that $\mathrm{Al}^{3+}$, $\mathrm{Fe}^{3+}, \mathrm{Zn}^{2+}$ and $\mathrm{Pb}^{2+}$ are from the same source or origin.

\section{Plant analysis}

Typha domingensis plant samples were collected from the study area at two different seasons (Winter and Summer 2008). Plant samples were separated into four parts namely 1) Roots and rhizomes, 2) Leaf bases, 3) Green leaf parts and 4) Yellow leaf parts. Control T. domingensis plant samples were also collected from 
Table 1: Mean and \pm SD of elemental and physicochemical characteristics of wastewater

\begin{tabular}{lc}
\hline Measured parameter & Concentration in $\mathrm{mg} / \mathrm{L}$ \\
\hline TDS & 1396 \\
Total Kjeldahl N & 531.5 \\
Total P & $5.32 \pm 0.02$ \\
$\mathrm{Na}^{+}$ & $377.10 \pm 13.6$ \\
$\mathrm{Mg}^{2+}$ & $30.83 \pm 1.2$ \\
$\mathrm{~K}^{+}$ & $34.41 \pm 1.5$ \\
$\mathrm{Ca}^{2+}$ & $75.97 \pm 4.0$ \\
$\mathrm{Al}^{3+}$ & $6.56 \pm 0.4^{* *}$ \\
$\mathrm{Cr}^{3+}$ & $0.11 \pm 0.02$ \\
$\mathrm{Mn}^{2+}$ & $0.17 \pm 0.03$ \\
$\mathrm{Fe}^{3+}$ & $10.46 \pm 0.28^{* *}$ \\
$\mathrm{Ni}^{2+}$ & $0.02 \pm 0.007$ \\
$\mathrm{Cu}^{2+}$ & $0.29 \pm 0.06$ \\
$\mathrm{Zn}^{2+}$ & $3.87 \pm 0.09^{* *}$ \\
$\mathrm{As}^{3+}$ & $\mathrm{ND}$ \\
$\mathrm{Cd}^{2+}$ & $\mathrm{ND}$ \\
$\mathrm{Pb}^{2+}$ & $0.99 \pm 0.01^{* *}$ \\
\hline
\end{tabular}

*ND = not detected; ** Higher than the limits of the Egyptian environmental regulations which are 3, 1.5, 1 and $0.05 \mathrm{mg} / \mathrm{L}$ for $\mathrm{Al}^{3+}, \mathrm{Fe}^{3+}, \mathrm{Zn}^{2+}$ and $\mathrm{Pb}^{2+}$ respectively. $\mathrm{ND}=$ not detected

unpolluted area nearby the study area. No yellow leaf parts were found in the control samples.

A graphical comparison for the accumulation of $\mathrm{Al}^{3+}$, $\mathrm{Fe}^{3+}, \mathrm{Zn}^{2+}$ and $\mathrm{Pb}^{2+}$ in different Typha parts during Summer and Winter seasons as compared to control is given in Fig. 1 and the results are summarized in Table 3.

It was also observed that all the studied elements concentrations in different plant parts were significantly higher $(\mathrm{p}<0.05)$ in Summer than in Winter.

The statistical analysis results for the comparison of means for control, Winter and Summer elements concentrations in different $T$. domingensis parts showed that $\mathrm{Al}^{3+}, \mathrm{Fe}^{3+}, \mathrm{Zn}^{2+}$ and $\mathrm{Pb}^{2+}$ concentrations in plant tissues from the wastewater pond were significantly higher $(\mathrm{p}<0.05)$ than in the control plant.

Further the statistical analysis for the comparison of mean elements accumulation in different plant parts in the wastewater pond showed that: 1) $\mathrm{Al}^{3+}$ accumulation varied significantly $(\mathrm{p}<0.05)$ between the different $T$. domingensis parts following the order: yellow parts $>$ roots and rhizomes $>$ leaf bases $>$ green parts; 2) $\mathrm{Fe}^{3+}$ and $\mathrm{Zn}^{2+}$ accumulated in the order: roots and rhizomes $>$ leaf bases $>$ yellow parts $>$ green parts; with significant differences $(\mathrm{p}<0.05)$, except between yellow and green leaf parts; and 3) $\mathrm{Pb}^{2+}$ accumulation varied significantly $(\mathrm{p}<0.05)$ following the order: roots and rhizomes $>$ leaf bases $>$ green parts $>$ yellow parts, with no significant differences between the accumulation in yellow and green leaf parts.

Comparing the elements concentrations accumulated by different $T$. domingensis parts with the phytotoxic values previously reported in literature showed that aluminium concentration in all plant parts (except the green parts) exceeded the phytotoxic limit for aluminium in plants which is $>100 \mathrm{mg} / \mathrm{Kg}$ (Dobermann and Fairhurst, 2000). Many toxic effects of aluminium on plant growth have been previously reported. Among the toxic effects of $\mathrm{Al}^{3+}$ on plants is the reduction of chlorophyll pigment quantity as well as the ratio between chlorophyll a and b, which is accompanied by a marked decline in photosynthetic rate (Ajoy et al., 1998). These phenomena could be occurring in plants in the wastewater pond and be responsible for the observed yellowing of leaf parts.

Interestingly, the levels of $\mathrm{Fe}^{3+}, \mathrm{Zn}^{2+}$ and $\mathrm{Pb}^{2+}$ in the plant parts did not exceed the phytotoxic limit for these elements, which are in the range $400-1000 \mathrm{mg} / \mathrm{Kg}$, 200$500 \mathrm{mg} / \mathrm{Kg}$ and $30-300 \mathrm{mg} / \mathrm{Kg}$ for $\mathrm{Fe}^{3+}, \mathrm{Zn}^{2+}$ and $\mathrm{Pb}^{2+}$ respectively (Levy et al., 1999; Romheld and Marschner, 1991).

\section{$B C F$ and TF}

After analyzing the results of $\mathrm{Al}^{3+}, \mathrm{Fe}^{3+}, \mathrm{Zn}^{2+}$ and $\mathrm{Pb}^{2+}$ accumulation by different plant parts, two important factors were studied to understand the possible role of $T$. domingensis in phytoremediation. The two investigated factors are 1) the TF and 2) BCF, also called enrichment coefficient. Both BCF and TF can be used to estimate a plant's potential for phytoremediation purpose (Yoon, 2006).

TFs are used to determine the effectiveness of a plant in the translocation of metals from the roots to the shoots (Tu and Ma, 2002). Both the BCF and the $\mathrm{TF}$ are considered when investigating whether a plant is a hyperaccumulator of a metal (Gonzaga et al., 2006). When BCFs $>1$ indicate that the plant is an "accumulator", $<1$ indicate the plant is an "excluder" (Baker, 1981). TFs $>1$ indicate the plant is effective in the translocation of a metal from root to shoot tissue (Ma et al., 2001). The TF of the studied elements are shown in Table 4. The TF values ranged between 0.118 and 0.357 . The TFs for the studied elements were generally lower than 1.0 indicating that $T$. domingensis 
Int. J. Environ. Sci. Tech., 8 (3), 639-648, Summer 2011

Table 2: Comparison between the tested metals concentration in sediments and the normal; critical ranges of metals in soils and sediments, and eco-toxic ranges of metals in sediments

\begin{tabular}{lccrc}
\hline Metal ions & $\begin{array}{c}\text { Concentration in tested } \\
\text { samples }(\mathrm{mg} / \mathrm{Kg})\end{array}$ & $\begin{array}{c}\text { Common } \\
\text { range in soils } \\
(\mathrm{mg} / \mathrm{Kg})^{*}\end{array}$ & $\begin{array}{c}\text { Critical range in soil } \\
(\mathrm{mg} / \mathrm{Kg})^{* *}\end{array}$ & $\begin{array}{c}\text { Eco-toxic threshold values in } \\
\text { sediments } \\
(\mathrm{mg} / \mathrm{Kg})^{* * *}\end{array}$ \\
\hline $\mathrm{Al}^{3+}$ & $2879.50 \pm 45.7$ & $10,000-300,000$ & - & - \\
$\mathrm{Fe}^{3+}$ & $5264.75 \pm 25.7$ & $7,000-550,000$ & - & - \\
$\mathrm{Zn}^{2+}$ & $904.35 \pm 11.1$ & $10-300$ & $70-400$ & 47 \\
$\mathrm{~Pb}^{2+}$ & $59.13 \pm 2.3$ & $2-200$ & $30-300$ & 150 \\
\hline
\end{tabular}

* Naturally occurring in the soil (Denga et al., 2004);** Data after Kabata and Pendias (Kabata and Pendias, 1992); ***Ecotoxic threshold values established by EPA in the sediment (EPA, 1996)

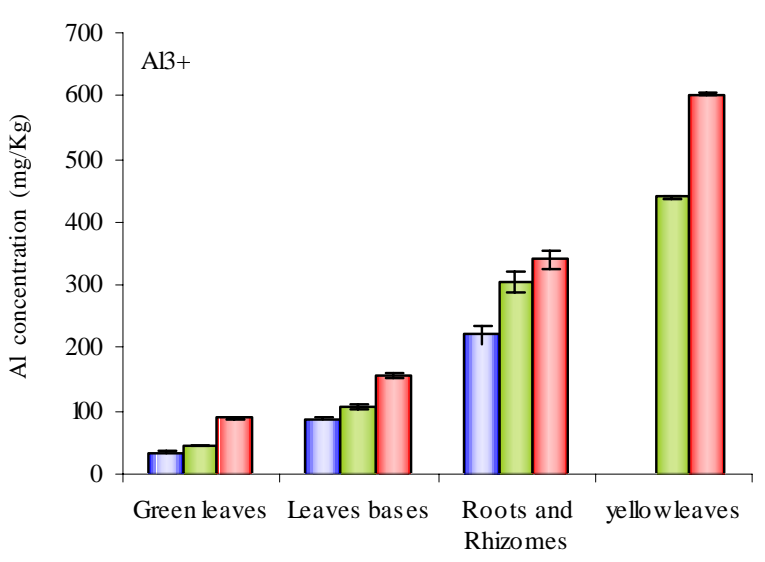

a Control

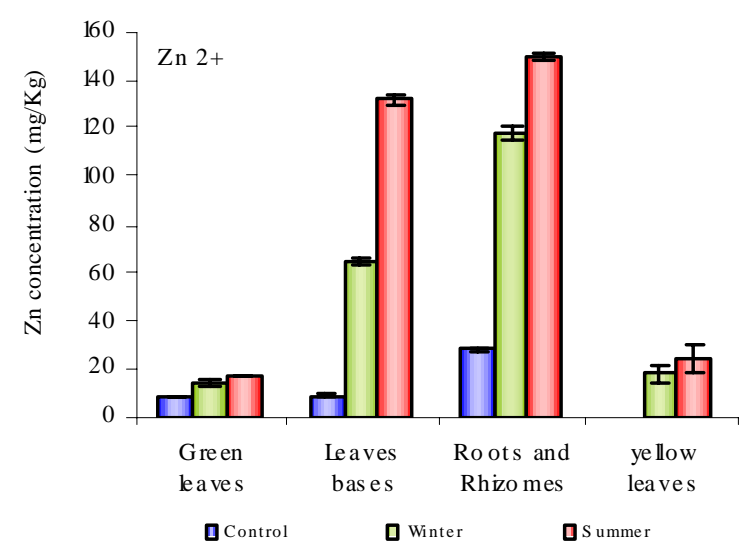

Fig. 1: Accumulation of $\mathrm{Al}^{3+}, \mathrm{Fe}^{3+}, \mathrm{Zn}^{2+}$ and $\mathrm{Pb}^{2+}$

did not effectively transfer the studied elements from root to shoot i.e. the plant accumulates metals in the below ground parts (roots / rhizomes) better than in the above ground parts (shoot / leaf). The uptake ability for the roots of $T$. domingensis towards the studied elements was in the following order: $\mathrm{Pb}^{2+}>\mathrm{Fe}^{3+}>\mathrm{Al}^{3+}>\mathrm{Zn}^{2+}$
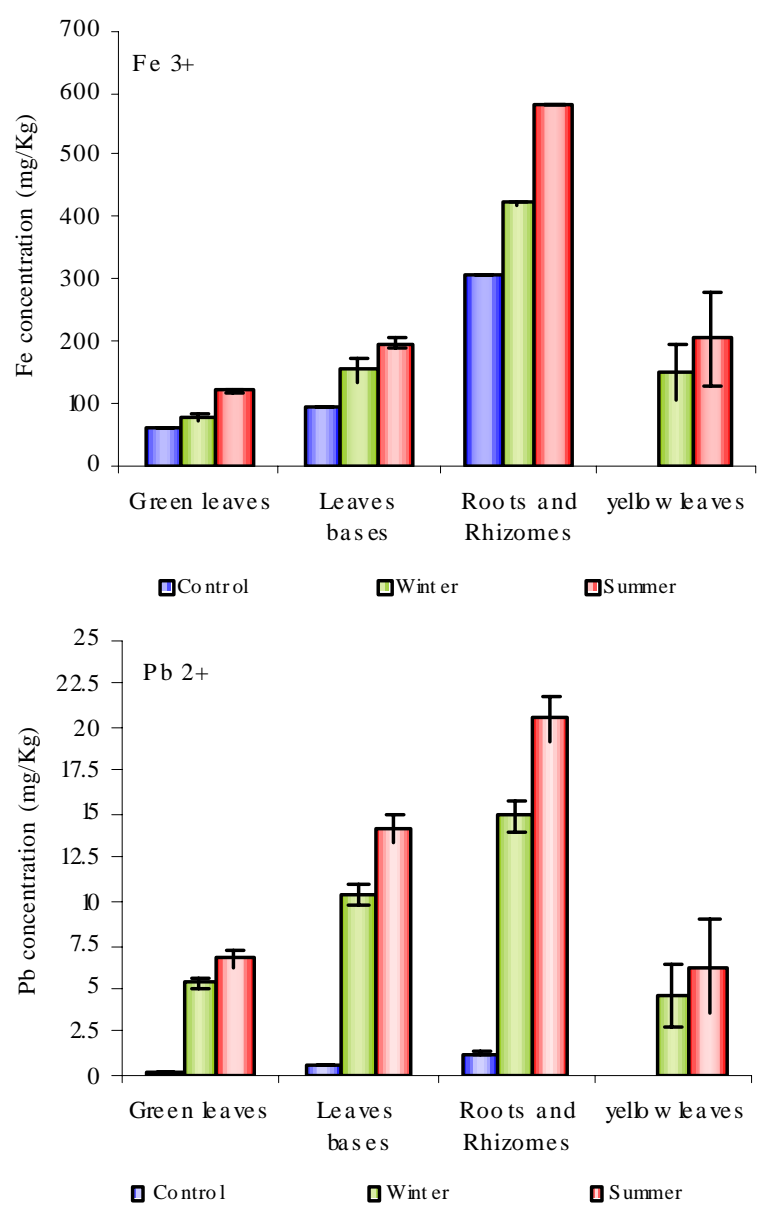

in different plant parts in Summer and Winter seasons

BCF is a common important factor when considering the phytoremediation potential of a given species (Zhao et al., 2003). In this study, $\mathrm{BCF}$ values of $\mathrm{Al}^{3+}, \mathrm{Fe}^{3+}, \mathrm{Zn}^{2+}$ and $\mathrm{Pb}^{2+}$ (Table 4), were greater than 1 which indicated the phytoremediation potential of $T$. domingensis for these metals. Baker (1981) concluded that any species may act as an accumulator, an indicator and excluder 
Table 3: Mean values and $\pm \mathrm{SD}$ of concentrations in different plant parts of $T$. domingensis growing in control site and industrial wastewater pond in different seasons

\begin{tabular}{|c|c|c|c|c|c|c|c|c|c|c|c|}
\hline \multirow{2}{*}{ Element } & \multicolumn{3}{|c|}{$\begin{array}{l}\text { Elements concentrations } \\
\text { in control plant (mg/Kg) }\end{array}$} & \multicolumn{4}{|c|}{$\begin{array}{c}\text { Elements accumulation } \\
\text { in Typha parts in Winter (mg/Kg) }\end{array}$} & \multicolumn{4}{|c|}{$\begin{array}{l}\text { Elements accumulation } \\
\text { in Typha parts in Summer (mg/Kg) }\end{array}$} \\
\hline & $\begin{array}{l}\text { Roots and } \\
\text { rhizomes }\end{array}$ & $\begin{array}{l}\text { Leaf } \\
\text { bases }\end{array}$ & $\begin{array}{l}\text { Green } \\
\text { parts }\end{array}$ & $\begin{array}{l}\text { Roots and } \\
\text { rhizomes }\end{array}$ & $\begin{array}{l}\text { Leaf } \\
\text { bases }\end{array}$ & $\begin{array}{l}\text { Green } \\
\text { parts }\end{array}$ & $\begin{array}{l}\text { Yellow } \\
\text { parts }\end{array}$ & $\begin{array}{l}\text { Roots and } \\
\text { rhizomes }\end{array}$ & $\begin{array}{l}\text { Leaf } \\
\text { bases }\end{array}$ & $\begin{array}{l}\text { Green } \\
\text { parts }\end{array}$ & $\begin{array}{l}\text { Yellow } \\
\text { parts }\end{array}$ \\
\hline \multirow{2}{*}{$\mathrm{Al}^{3+}$} & 220.82 & 87.64 & 34.60 & 303.91 & 106.92 & 44.25 & 439.8 & 350.55 & 156.55 & 89.18 & 602.39 \\
\hline & \pm 13.52 & \pm 1.08 & \pm 0.52 & \pm 16.12 & \pm 3.03 & \pm 0.66 & \pm 2.03 & \pm 13.71 & \pm 2.86 & \pm 2.91 & \pm 3.21 \\
\hline $\mathrm{Fe}^{3+}$ & 307.5 & 95.76 & 62.42 & 423.20 & 154.68 & 78.83 & 148.89 & 582.44 & 196.68 & 119.76 & 203.94 \\
\hline \multirow{2}{*}{$\mathrm{Zn}^{2+}$} & 28.06 & 9.12 & 7.46 & 117.64 & 63.90 & 13.95 & 17.89 & 149.60 & 131.63 & 17.44 & 24.50 \\
\hline & \pm 1.04 & \pm 0.08 & \pm 0.31 & \pm 2.26 & \pm 1.86 & \pm 1.19 & \pm 3.86 & \pm 0.89 & \pm 2.96 & \pm 0.25 & \pm 5.83 \\
\hline \multirow[t]{2}{*}{$\mathrm{Pb}^{2+}$} & 1.26 & 0.65 & 0.047 & 14.87 & 10.36 & 5.30 & 4.61 & 20.46 & 14.19 & 6.78 & 6.32 \\
\hline & \pm 0.13 & \pm 0.01 & \pm 0.01 & \pm 0.83 & \pm 0.596 & \pm 0.36 & \pm 1.75 & \pm 1.33 & \pm 0.82 & \pm 0.46 & +2.77 \\
\hline
\end{tabular}

The data presented are mean values of four replicates + standard deviation

Table 4: BCF and TF of $\mathrm{Al}^{3+}, \mathrm{Fe}^{3+}, \mathrm{Zn}^{2+}$ and $\mathrm{Pb}^{2+}$

\begin{tabular}{cccccc}
\hline Metals & $\begin{array}{c}\text { BCF } \\
\text { (shoot / sediment) }\end{array}$ & $\begin{array}{c}\text { BCF } \\
\text { (root / sediment) }\end{array}$ & $\begin{array}{c}\text { BCF } \\
\text { (shoot / wastewater) }\end{array}$ & $\begin{array}{c}\text { BCF } \\
\text { (root / wastewater) }\end{array}$ \\
\hline $\mathrm{Al}^{3+}$ & $0.015+0.0004$ & $0.105 \pm 0.004$ & $6.78 \pm 0.55$ & $46.37 \pm 1.28$ \\
$\mathrm{Fe}^{3+}$ & $0.015 \pm 0.0005$ & $0.080 \pm 0.004$ & $7.63 \pm 0.42$ & $40.48 \pm 1.03$ \\
$\mathrm{Zn}^{2+}$ & $0.015 \pm 0.0014$ & $0.130 \pm 0.001$ & $3.61 \pm 0.34$ & $30.37 \pm 0.15$ \\
$\mathrm{~Pb}^{2+}$ & $0.089 \pm 0.0027$ & $0.251 \pm 0.010$ & $5.43 \pm 0.60$ & $15.27 \pm 2.04$ & $0.188+0.01$ \\
\hline
\end{tabular}

over different ranges of soil metal concentration. This factor indicates that $T$. domingensis is an effective metal accumulator.

The correlation coefficients of element concentrations in water, sediment and plant demonstrated a small number of significant, positive relationships (Table 5). In general, there were higher correlations between the concentrations of studied elements in T. domingensis roots and in water than in sediments. The results obtained in the present study were in agreement with the results reported in literature by Sasmaz et al. (2008) and Sutapa et al. (2008) for other Typha species.

Previous studies on the accumulation of various metal ions by aquatic plants have also shown that the accumulation of most metals was higher in roots than the other parts of plants (Satyakala and Jamil, 1992; Zaranyika and Ndapwadza, 1995; Chandra and Kulshreshtha, 2004). This is consistent with the findings of the present study.

These results further support the efficacy of T. domingensis in phytoremediation purposes. Phytoremediation comprises different strategies used by plants to decontaminate soil and water, namely, rhizofiltration, phytostabilization, phytodegradation, phytoextraction, and phytovolatilization (US EPA, 1998).

The results could be explained in terms of "rhizofiltration" which involves the removal of aqueous pollutants by the plant root system (Dushenkov, 1995; Dushenkov and Kapulnik, 2000). Rhizofiltration is a promising alternative to the conventional clean-up methods, a phytoremediative technique designed for the removal of metals in aquatic environments. The process involves raising plants hydroponically and transplanting them into metalpolluted waters where plants absorb and concentrate the metals in their roots and shoots (Dushenkov et al., 1995; Salt et al., 1995; Flathman and Lanza, 1998; Zhu et al.,1999). Root exudates cause changes in rhizosphere $\mathrm{pH}$ and may cause metals to precipitate onto root surfaces. As they become saturated with the metal contaminants, roots or whole plants are harvested for disposal (Flathman and Lanza, 1998; Zhu et al.,1999).

Fig. 2 shows the pathway of metals uptake in plants (Wendy et al., 2005). For many contaminants, passive uptake via micropores in the root cell walls (the apoplastic pathway) may be a major route into the root, where sequestration or degradation can take place. The 


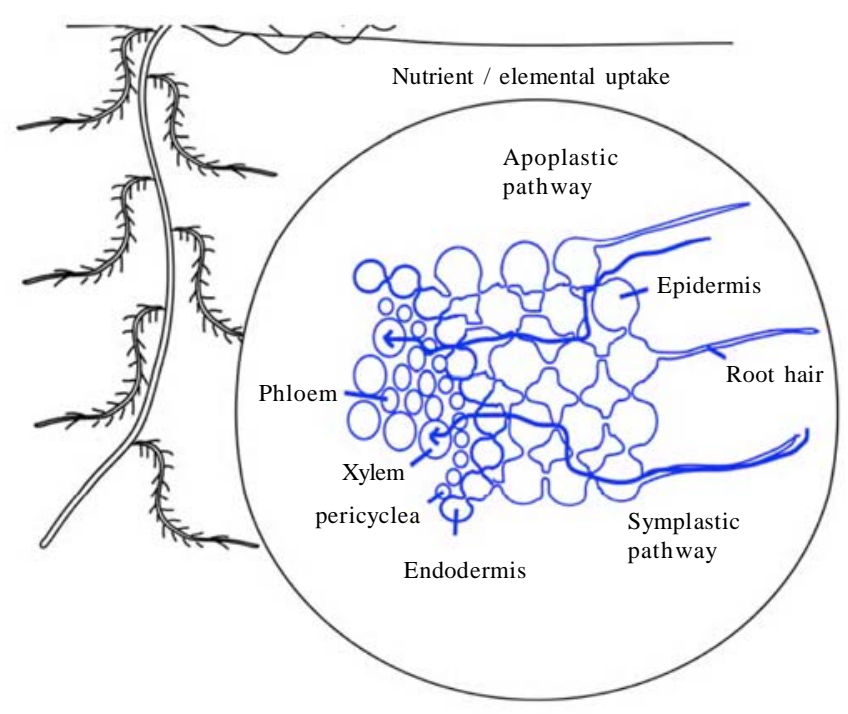

Fig. 2: Pathway of metals uptake in plants (Wendy et al., 2005)

Table 5: Correlation matrix between elements concentrations in water, sediment and plant

\begin{tabular}{|c|c|c|c|c|c|}
\hline & & $A l_{W}$ & $A l_{S}$ & $A l_{p r}$ & $A l_{p s}$ \\
\hline \multirow[t]{4}{*}{$\overline{\mathrm{Al}^{3+}}$} & $A l_{W}$ & 1 & & & \\
\hline & $A l_{S}$ & $1.000^{* *}$ & 1 & & \\
\hline & $A l_{p r}$ & 0.946 & 0.942 & 1 & \\
\hline & $A l_{p s}$ & -0.370 & -0.348 & -0.468 & 1 \\
\hline \multirow[t]{5}{*}{$\mathrm{Fe}^{3+}$} & & $F e_{W}$ & $\mathrm{Fe}_{S}$ & $F e_{p r}$ & $F e_{p s}$ \\
\hline & $F e_{W}$ & 1 & & & \\
\hline & $\mathrm{Fe}_{S}$ & $0.977^{* *}$ & 1 & & \\
\hline & $F e_{p r}$ & 0.545 & 0.568 & 1 & \\
\hline & $F e_{p s}$ & -0.663 & -0.602 & 0.028 & 1 \\
\hline \multirow[t]{5}{*}{$\mathrm{Zn}^{2+}$} & & $Z n_{W}$ & $Z n_{S}$ & $Z n_{p r}$ & $Z n_{p s}$ \\
\hline & $Z n_{W}$ & 1 & & & \\
\hline & $Z n_{S}$ & $0.968^{*}$ & 1 & & \\
\hline & $Z n_{p r}$ & $0.980^{*}$ & $0.984^{*}$ & 1 & \\
\hline & $Z n_{p s}$ & -0.429 & -0.463 & -0.325 & 1 \\
\hline \multirow[t]{5}{*}{$\mathrm{Pb}^{2+}$} & & $P b_{W}$ & $P b_{S}$ & $P b_{p r}$ & $P b_{p s}$ \\
\hline & $P b_{W}$ & 1 & & & \\
\hline & $P b_{S}$ & 0.808 & 1 & & \\
\hline & $P b_{p r}$ & $0.990^{* *}$ & 0.507 & 1 & \\
\hline & $P b_{p s}$ & 0.883 & 0.635 & 0.559 & 1 \\
\hline
\end{tabular}

**Correlation is significant at the 0.01 level (2-tailed); * Correlation is significant at the 0.05 level (2-tailed), where: $M_{w}, M_{S}, M_{p r}$ and $M_{p s}$ are metal ion ( $M$ ) concentrations in water, sediment, plant roots and plant shoots, respectively

apoplast is a hydrated free space continuum between the external soil solution and the cell membranes of the root cortex and vascular tissue. The cell wall micropores exist within a network of cellulose, hemicellulose, pectins, and glucoprotein containing many negative charges (generated by carboxylic groups) that act as cation binding sites and exchangers and as anion repellers. Di- and polyvalent cations (the form of many heavy metal and radionuclide contaminants) are preferentially attracted to, and bound on, these cation exchange sites within the root cortex cell walls (Negri et al., 1996). Some researchers believe that plants for 
phytoremediation should accumulate metals only in the roots (Dushenkov et al., 1995; Salt et al., 1995; Flathman and Lanza, 1998). Dushenkov et al. (1995) explained that the translocation of metals to shoots may decrease the efficiency of rhizofiltration by increasing the amount of contaminated phytomass which will need disposal. Phytoremediation differs from other pollutant treatment systems, which may have only one specific pollutant removal mechanism, in that several strategies, such as planned periodic harvests or natural dieback of aerial shoot of plant biomass to eliminate the accumulated metals, can be employed (Louis and Isebrands, 2005). Then when harvest comes after the plants have performed their phytoremediation role, the potential exists for the use of the harvested phytomass for further extraction of metals from the harvested material. Previous studies on $T$. domingensis proved the qualification of the species biomass as metals biosorbent (Abdel-Ghani et al., 2009a; b).

\section{CONCLUSION}

The concentrations of $\mathrm{Al}^{3+}, \mathrm{Fe}^{3+}, \mathrm{Zn}^{2+}$ and $\mathrm{Pb}^{2+}$ in wastewater ponds in the study area exceeded the upper limits indicated by the Egyptian environmental regulations. The native aquatic plant species T. domingensis accumulates high concentrations of $\mathrm{Al}^{3+}, \mathrm{Fe}^{3+}, \mathrm{Zn}^{2+}$ and $\mathrm{Pb}^{2+}$ in their roots. There were significantly positive relationships between the concentrations of $\mathrm{Al}^{3+}, \mathrm{Fe}^{3+}, \mathrm{Zn}^{2+}$ and $\mathrm{Pb}^{2+}$ in the T. domingensis roots and those in water. T. domingensis $L$. has the potential to be used in phytoremediation purposes to remove metal pollutants from contaminated wastewaters.

\section{REFERENCES}

Abdel-Ghani, N. T.; El-Chaghaby, G. A., (2008). The use low cost, environmental friendly materials for the removal of heavy metals from aqueous solutions. Curr. World Environ., 3 (1), 31-38 (8 pages).

Abdel Ghani, N. T.; Hegazy, A. K.; El-Chaghaby, G. A., (2009). Typha domingensis leaf powder for decontamination of aluminium, iron, zinc and lead: Biosorption kinetics and equilibrium modeling. Int. J. Environ. Sci. Tech., 6 (2), 243-248 (6 pages).

Abdel Ghani, N. T.; Hegazy, A. K.; El-Chaghaby, G. A., (2009). Factorial experimental design for biosorption of iron and zinc using Typha domingensis phytomass. Desalination, 249 (1), 343-347 (5 pages).

Ajoy, K. R.; Archana, S.; Geeta, T., (1998). Some aspects of aluminum toxicity in plants. Botan. Rev., 54 (2), 145-178 (34 pages).
Al-Anber, Z. A.; Matouq, M. A. D., (2008). Batch adsorption of cadmium ions from aqueous solution by means of olive cake. J. Hazard. Mater., 151 (1), 194-201 (8 pages).

AOAC, (2002a). Official Methods of Analysis. 17 $7^{\text {th. }}$ Ed., Association of Official Analytical Chemists, Washington, DC. AOAC official method \# 990.08.

AOAC, (2002b). Official Methods of Analysis. 17 ${ }^{\text {th. }}$ Ed., Association of Official Analytical Chemists, Washington, DC. AOAC official method \#985.01.

APHA; AWWA; WEF, (1998). Standard methods for the examination of water and wastewater. $20^{\text {th. }}$ Ed. American Public Health Association, American Water Works Association and the Water Environment Federation. Washington DC., USA.

Baker, A. J. M., (1981). Accumulators and excluder: strategies in response of plants to heavy metals. J. Plant Nutri., 3 (1-4), 643-654 (12 pages).

Boulos, L., (2009). Flora of Egypt checklist. Revised annotated edition. Al-Hadara publishing, Cairo.

Chandra, P.; Kulshreshtha, K.. (2004). Chromium accumulation and toxicity in aquatic vascular plants. Botan. Rev., 70 (3), 313-327 (14 pages).

Daifullah, A. A. M.; Girgis, B. S.; Gad, H. M. H., (2003). Utilization of agro-residues (Rice Husk) in small wastewater treatment plans. Mater. Lett., 57 (11), 1723-1731 (10 pages).

David, D.; Fiona, H.; Michelle, W.; Australian Water Quality Center, (2007). EPA Guidelines: Regulatory monitoring and testing Water and wastewater sampling.

Dekov, V. M.; Komy, Z.; Araujo, F.; Van Put, A.; Van Grieken, R., (1997). Chemical composition of sediments, suspended matter, river water and groundwater of the Nile (AswanSohag traverse). Sci. Total Environ., 201 (3), 195-210 (16 pages).

Denga, H.; Yea, Z. H.; Wonga, M. H., (2004). Accumulation of lead, zinc, copper and cadmium by 12 wetland plant species thriving in metal-contaminated sites in China. Environ. Pollut., 132 (1), 29-40 (42 pages).

Dobermann, A.; Fairhurst, T., (2000). Nutrient disorders and nutrient management. Handbook series.

Dushenkov, S.; Kapulnik, Y., (2000). Phytofilitration of metals." In: Phytoremediation of toxic metals - using plants to clean-up the environment. New York, John Wiley and Sons, Inc.

Dushenkov, V.; Kumar, P.; Motto, H.; Raskin, I., (1995). Rhizofiltration: the use of plants to remove heavy metals from aqueous streams. Environ. Sci. Tech., 29 (5), 12391245 (7 pages).

EEAA, (1994). Law number 4 of 1994 Promulgating the environmental law and its executive regulation, Egypt.

EEAA, (2002). Industrial Wastewater Treatment Plants Inspection Manual. Egyptian Environmental Affairs Agency.

Evangelou, V. P., (1998). Environmental soil and water chemistry principles and applications. Iowa state university, Iowa john Wiley and sons, Inc. New York.

Ezzat, M. N.; Shehab, H.; Hassan, A. A.; El Sharkawy, M.; El Diasty, A.; El Assiouty, I.; El-Gohary, F. and Tczap, A. (2002). Survey of Nile system pollution sources: Report No. 64. APRP Water Policy Program. 
Flathman, P. E.; Lanza, G. R., (1998). Phytoremediation: current views on an emerging green technology. J. Soil Contamin., 7 (4), 415-432 (33 pages).

Forstner, U.; Salomons, W., (1991). Mobilization of metals from sediments. Merian, E. (Ed.). Metals and their compounds in the environment: Occurrence and analysis and biological relevance, $\mathrm{VCH}$ (Germany) (Verlagsgesellschaft mbH).

Gonzaga, M. I. S.; Santos, J. A. G.; Ma, L. Q., (2006). Arsenic phytoextraction and hyperaccumulation by fern species. Scientia Agricola (Piracicaba, Braz.). 63 (1), 90-101 (12 pages).

Hamza, A., (2001). Guidelines on environment friendly industrial cities. Technical Publication, Ministry of State for Environmental Affairs, Egypt.

Janel, E. O.; Emily, D. N., (2006). Analysis of chemical contamination within a canal in a Mexican border colonia. Environ. Pollut., 140 (3), 506-515 (10 pages).

Kabata-Pendias, A.; Pendias, H., (1992). Trace Elements in

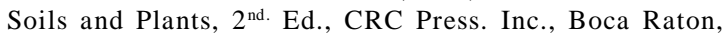
Florida.

Levy, D. B.; Redente, E. F.; Uphoff, G. D., (1999). Evaluation of the phytotoxicity of $\mathrm{Pb}-\mathrm{Zn}$ tailings to big bluestem (Andropogon gerardii Vitman) and switchgrass (Panicum $\begin{array}{llll}\text { virgatum L.). Soil Sci., } 164 & \text { (6), 363-375 }\end{array}$ (13 pages).

Lindsay, W. L., (1979). Chemical equilibria in soils. Willey, NewYork.

Louis, A. L.; Isebrands, J. G., (2005). Linking phytoremediated pollutant removal to biomass economic opportunities. Biomass Bioenerg., $28 \quad$ (2), 203-218 (16 pages).

Ma, L. Q.; Komar, K. M.; Tu, C.; Zhang, W.; Cai, Y.; Kennelly, E. D., (2001). A fern that hyperaccumulates arsenic. Nature Biotech., 409, 579 (1 page).

Maria, T. D.; Teodoro, M.; Jose, M. M.; Rainer, S.; Brett, H. R., (2008). Trace element accumulation in woody plants of the Guadiamar Valley, SW Spain: A large-scale phytomanagement case study. Environ. Pollut., 152 (1), 50-59 (10 pages).

Mercedes, L.; Paul, K.; Chris, H.; Geoff, M.; Gavin, F.; Charles, E., (1998). Review of environmental performance indicators for toxic contaminants in the environment - air, water and land. Technical Paper \# 37. Ministry for the Environment.

Negri, M.C.; Hinchman, R .R.; Gatliff E . G., (1996). Phytoremediation: Using green plants to clean up contaminated soil, groundwater, and wastewater. International Phytoremediation Conference, May 8-10, 1996, Arlington, VA. International Business Communications, Southborough, MA.

Nouri, J.; Khorasani, N.; Lorestani, B.; Karami, M.; Hassani, A.H.; Yousefi, N., (2009). Accumulation of heavy metals in soil and uptake by plant species with phytoremediation potential. Environ. Earth Sci., 59 (2), 315-323 (9 pages).

Nouri, J.; Lorestani, B.; Yousefi, N.; Khorasani, N.; Hasani, A. H.; Seif, S.; Cheraghi, M., (2011). Phytoremediation potential of native plants grown in the vicinity of Ahangaran lead-zinc mine (Hamedan, Iran). Environ. Earth Sci., 62 (3), 639-644 (6 pages).

Phillips, I. R., (2002). Phosphorus sorption and nitrogen transformation in two soils treated with piggery wastewater.
Aust. J. Soil Res., 40 (2), 335-349 (15 pages)

Riffat, S.; Arefin, M. T.; Mahmud, R., (2007). Phytoremediation of Boron Contaminated Soils by Naturally Grown Weeds. J. Soil Nature, 1(1): 01-06 (6 pages).

Romheld, V.; Marschner, H., (1991). Function of micronutrients in plants. In JJ Mortvedt, FR Cox, LM Shuman, RM Welch, eds, Micronutrients in Agriculture, Ed 2. Soil Science Society of America, Madison, Wl.

Sharifi, M.; Sadeghi, Y.; Akpapour, M., (2007). Germination and growth of six plant species on contaminated soil with spent oil. Int. J. Environ. Sci. Tech., 4 (4), 463-470 (8 pages).

Salt, D.E.; Blaylock, M.; Kumar, N. P. B. A.; Dushenkov, V.; Ensley, D.; Chet, I.; Raskin, I., (1995). Phytoremediation: a novel strategy for the removal of toxic metals from the environment using plants. Biotech., 13, 468-474 (7 pages).

Sasmaz, A.; Erdal, O.; Halil, H., (2008). The accumulation of heavy metals in Typha latifolia L. grown in a stream carrying secondary effluent. Ecologic. Eng., 33 (3-4), 278-284 (7 pages).

Satyakala, G.; Jamil, K., (1992). Chromium-induced biochemical changes in Eichhornia crassipes (Mart) solms and Pistia stratiotes L. Bull. Environ. Contaminat. Toxicol., 48 (6), 921-928 (8 pages).

Singh, S. K.; Juwarkar, A. A.; Kumar; S.; Meshram, J.; Fan, M., (2007). Effect of amendment on phytoextraction of arsenic by Vetiveria Zizanioides from soil. Int. J. Environ. Sci. Tech., 4 (3), 339-344 (6 pages).

Sutapa, B.; Bhattacharyya, A. K., (2008). Heavy metal accumulation in wheat plant grown in soil amended with industrial sludge. Chemosphere, 70 (7), 1264-1272 (9 pages).

Sutapa, B.; Jagruti, V. ; Vivek, R.; Ramanathan, A. L., (2008). Metal uptake and transport by Tyaha angustata $L$. grown on metal contaminated waste amended soil: An implication of phytoremediation. Geoderma, 145 (1-2), 136-142 (7 pages).

Tu, C. ; Ma, L. Q., (2002). Effect of Arsenic concentrations and Forms on Arsenic Uptake by Hyperaccumulator Ladder Brake Fern. J. Environ. Qual., 31 (2), 641-647 (7 pages).

US EPA, (1996). Eco Update: Ecotox Thresholds. Office of Solid Waste and Emergency Response. Washington, D.C.

US EPA, (2001). A citizen's Guide to Phytoremediation. EPA publication 542-F-98-011.

US EPA, (2002). National Recommended_Water Quality Criteria: 2002. Office of Water, Office of Science and Technology, Washington, DC.

Wendy, A. P.; Baxter, I. R.; Richards, E. L.; Freeman, J. L.; Murphy, A. S., (2005). Phytoremediation and hyperaccumulator plants. In Topics in Current Genetics, Volume 14/2006 , M. J. Tamas, E Martinoia (Eds.). Molecular Biology of Metal Homeostasis and Detoxification.

Yale Center for Environmental Law and Policy, (2008). Environmental Performance Index: Water Quality Index.

Yoon, J.; Xinde, C.; Qixing, Z. and Lena, Q. M., (2006). Accumulation of $\mathrm{Pb}, \mathrm{Cu}$, and $\mathrm{Zn}$ in native plants growing on a contaminated Florida site. Sci. Total Environ., 368 (2-3), 456464 (9 pages).

Zaranyika, M. F.; Ndapwadza, T., (1995). Uptake of Ni, Zn, Fe, $\mathrm{Co}, \mathrm{Cr}, \mathrm{Pb}, \mathrm{Cu}$ and $\mathrm{Cd}$ by water hyacinth (Eichhornia crassipes) in Mukuvsi and rivers, Zimbabwe. J. Environ. Sci. Health A., 30 (1), 1157-1169 (13 pages). 
Zhao F. J., Lombi, E.; McGrath, S. P., (2003). Assessing the potential for zinc and cadmium phytoremediation with the hyperaccumulator Thlaspi caerulescens. Plant Soil, 249 (1), 37-43 (7 pages)

Zhang, H.; Dang, Z.; Zheng, L. C.; Yi, X. Y., (2009). Remediation of soil co-contaminated with pyrene and cadmium by growing maize (Zea mays L.). Int. J. Environ. Sci. Tech., 6 (2), 249-258 (10 pages)

Zhu, Y. L.; Zayed, A. M.; Quian, J. H.; De Souza, M.; Terry, N. (1999). Phytoaccumulation of trace elements by wetland plants: II. Water hyacinth. J. Environ. Qual., 28 (1),339344 (6 pages).

\section{AUTHOR (S) BIOSKETCHES}

Hegazy, A. K., Ph.D., Professor, Department of Botany and Microbiology, College of Science, King Saud University, Riyadh, Saudi Arabia. Email: akhegazy@yahoo.com

Abdel-Ghani, N. T., Ph.D., Professor, Department of Chemistry, Faculty of Science, Cairo University, Egypt. Email: noureta2002@yahoo.com

El-Chaghaby, G. A., Ph.D., Researcher, Agricultural Research Center, Egypt. Email: ghadiraly@yahoo.com

How to cite this article: (Harvard style)

Hegazy, A. K.; Abdel-Ghani, N. T.; El-Chaghaby, G. A., (2011). Phytoremediation of industrial wastewater potentiality by Typha domingensis. Int. J. Environ. Sci. Tech., 8 (3), 639-648. 